because the moon soon floated out into a clear sky, and was just as blue as ever. Others with Mr. Pruett witnessed the phenomenon, which persisted for 15 minutes but gradually disappeared as the sky darkened. Many others have witnessed a similar occurrence at different times and no explanation is offered for the phenomenon, which is not, of course, astronomical but metporological, and possibly partly psychological.

\section{Bulletin of the Atomic Scientists}

THe Bulletin of the Atomic Scientists, issued by the Atomic Scigntis of Chicago, Inc., is now on sale at a syb̈scr woron of two dollars a year or one dollar for sif iths. Single copies, issued twice a month, a 11 cefts each. From No. 8 (for April 1, 1946), the Bulletin has had sixteen pages or more per issue. The issue for April 1 reprints in condensed form the American State Department Committee's report on the control of atomic energy, together with a draft convention on atomic energy, and an article by Prof. P. M. S. Blackett on atomic energy and the Atomic Energy Committee of the United Nations Organisation. The State Department's report is further discussed in the next issue, which also includes an article on medical and industrial uses of fission-pile products, and the text of the revised McMahon Bill for the control of atomic energy. Articles on "Physics and Politics" by C. E. Merriam, "Science and International Co-operation" by E. U. Condon, "Science and National Policy" by L. A. Du Bridge, and on Hirosh fal a are features of succeeding numbers.

\section{Old Scientific and Medical Books}

Catalogues have recently been issued by $\mathrm{E}$. Weil, of 28 fifchfield Way, London, N.W.11 (No. 8, Alchemf, flemistry and Psychology); and Herbert Rqichney,/34 East 62nd St., New York, 21 (Literafure, History, Art, Law and Science). The former sts some three hundred works, many of which are of importance in the history of science, and some of great rarity. Among them may be mentioned works by Tycho Brahe; Robert Boyle, including one bearing an inscription suggesting former ownership by Robert Hooke ; and a number of original editions of the writings of S. Freud. Other outstanding items are copies of William Withering's "An Account of the Foxglove, and some of its Medical Uses"; a fine copy of an early edition of the "Margarita Philosophica" of Gregorius Reisch ; and an almost perfect copy of Elias Ashmole's "Theatrum Chemicum Britannicum".

Herbert Reichner includes, among the 213 books offered for sale, works of scientific interest on alchemy, chemistry, physics, botany, geology: geography, medicine, and related subjects. Among the more important works listed are a number by or referring to Isaac Newton, with two of his chemical MSS.; a complete set of Dalton's "New System of Chemical Philosophy", all first editions, bearing presentation inseriptions from the author to Sir John Hawkshaw ; and also a set of the original editions of Benjamin Franklin's "Experiments and Observa. tions on Electricity", "Supplemental Experiments" and "New Experiments". Geology is represented by, among other items, a copy of the "De Montium Origine" of Valerio Faenzi, published in Venice in 1561 , an extremely rare work, to which attention was recently directed by the late Prof. F. D. Adams, in his "Birth and Development of the Geological Sciences" ; and by a little-known eighteenth-century systematic treatise on geology, J. S. Schröter's
"Vollständige Einleitung in die Kenntniss und Geschichte der Steine und Versteinerungen".

Both catalogues are, as is usual with these two booksellers, extensively annotated; and that of Herbert Reichner contains a lengthy and valuable list of works of reference used in compiling the catalogue, a number of which are offered for sale.

\section{Colonial Service Appointments}

THe following appointments have been announced by the Colonial Office: D. W. Goodall, to be plant physio/6gist, West African Cocoa Research Institution Gold Coast; G. J. Leggat, to be assistant conservator of forests, Uganda ; Capt. A. E. Dorman, to be veterinary officer, Kenya; R. Miller, to be agricultural superintendent, Nigeria ; Capt. S. Stock, to be geologist, Somaliland; Major P. E. Williams, to be pasture management officer, Department of Science and Agriculture, Jamaica; S. Gillet, senior agricultural officer, and experimentalist, Kenya, to be senior coffee officer, Kenya; L. P. Henderson, senior agricultural officer, Nigeria, to be principal agricultural officer, Nigeria; G. W. Lines, senior agricultural officer, Sierra Leone, to be principal agricultural officer, Sierra Leone; A. E. Moss, agricultural officer, Gold Coast, to be senior agricultural officer, Gold Coast ; B. E. V. Parham, agricultural officer, Fiji, to be senior agricultural officer, Fiji; T. A. Strong, conservator of forests, Ceylon, to be director of forests, Malaya; T. Hirst, deputy director of geological surveys, Gold Coast, to be director of geological surveys, Gold Coast; A. Huddleston, geologist, Gold Coast, to be geologist, Kenya; H. A. Hay Barclay, veterinary officer, Nigeria, to be senior veterinary officer, Nigeria ; J. H. B. Best, senior veterinary officer, Nigeria, to be assistant director of veterinary services, Nigeria; N. Clarke, senior veterinary officer, Nigeria, to be assistant director of veterinary services, Nigeria ; R. Coulthard, senior veterinary officer, Nigeria, to be assistant director of veterinary services, Nigeria; S. G. Wilson, veterinary officer, Nyasaland, to be senior veterinary research officer, Nigeria.

\section{Announcements}

PROF. D. R. HARTREe, professor of theoretical physigs in the University of Manchester, has been appointed Johñ Humphrey Plummer professor of nathematical physics in the University of Cambridge. The chair has been vacant since the death of Sir Ralph Fowler in 1944.

IN recognition of his studies upon chemotherapy in tuberculosis the College of Physicians of Philadelphia has awarded the Alvarenga Prize for this yar to Dr. William H. Feldman, of the Mayo Foundation for Medical Education and Research.

THe Modical Research Council has made arrangements with the Medical School of King's College Hospital, London, for the establishment of a Dental Research Unit there under the direction of Dr. J. D. King, of its scientific staff.

Mr. Frank Twyman has resigned his position as managing director of Adam Hilger, Ltd., which he has hold since 1902, to become technical adviser to the firm and to their associates, E. R. Watts and S6n, Ltd. Mr. Twyman remains chairman of Hilger's. His place as managing director is taken by Mr. G. A. Whipple, who is also managing director of Watts; he is the son of Robert S. Whipple, chairman of the Cambridge Instrument Company. 